\title{
Aeromagnetic anomaly patterns reveal buried faults along the eastern margin of the Wilkes Subglacial Basin (East Antarctica)
}

\author{
E. Armadillo, ${ }^{1}$ F. Ferraccioli, ${ }^{2}$ A. Zunino, ${ }^{1}$ and E. Bozzo ${ }^{1}$ \\ ${ }^{1}$ Dipartimento per lo Studio del Territorio e delle Sue Risorse, Università di Genova, V.le Benedetto XV 5,16132 Genova, Italy \\ ${ }^{2}$ British Antarctic Survey, High Cross, Madingley Road, Cambridge CB3 OET, UK
}

\begin{abstract}
The Wilkes Subglacial Basin (WSB) is the major morphological feature recognized in the hinterland of the Transantarctic Mountains. The origin of this basin remains contentious and relatively poorly understood due to the lack of extensive geophysical exploration. We present a new aeromagnetic anomaly map over the transition between the Transantarctic Mountains and the WSB for an area adjacent to northern Victoria Land. The aeromagnetic map reveals the existence of subglacial faults along the eastern margin of the WSB. These inferred faults connect previously proposed fault zones over Oates Land with those mapped along the Ross Sea Coast. Specifically, we suggest a link between the Matusevich Frature Zone and the Priestley Fault during the Cenozoic. The new evidence for structural control on the eastern margin of the WSB implies that a purely flexural origin for the basin is unlikely.

Citation: Armadillo, E., F. Ferraccioli, A. Zunino and E. Bozzo (2007), Aeromagnetic anomaly patterns reveal buried faults along the eastern margin of the Wilkes Subglacial Basin (East Antarctica), in Antarctica: A Keystone in a Changing World - Online Proceedings of the $10^{\text {th }}$ ISAES, edited by A.K. Cooper and C.R. Raymond et al., USGS Open-File Report 2007-1047, Short Research Paper 091, 4 p.; doi:10.3133/of2007-1047.srp091
\end{abstract}

\section{Introduction}

The Transantarctic Mountains (TAM) form an uplifted flank of the West Antarctic Rift System. The Wilkes Subglacial Basin (WSB) is the main morphological feature over the ice-covered hinterland of the TAM (Drewry, 1976). It extends for more than $1200 \mathrm{~km}$ parallel to the range and is over $400 \mathrm{~km}$ wide at the George V Coast (Fig. 1).

Understanding the tectonic, origin and structural architecture of the WSB is important to improve our knowledge of the processes that led to large-magnitude uplift of the TAM (e.g. Stern and ten Brink, 1989; Fitzgerald, 2002, and references therein; Stern and Baxter, 2002). However, the WSB is relatively poorly known because of its ice cover and remoteness, which makes geophysical exploration difficult. Drewry (1976) and Steed (1983) first proposed that the WSB could represent a region of rifted continental crust. In contrast, Stern and ten Brink (1989) proposed a flexural origin for the basin linked to TAM uplift, which would imply that it is imposed upon thick and rigid East Antarctic Craton lithosphere. Ferraccioli et al. (2001) interpreted gravity, magnetic and radar data acquired along the ITASE traverse at $75 \mathrm{~S}$ to indicate that the WSB may instead represent a broad "extended terrane", based upon its width, crustal thickness, and thin sedimentary infill. As a new contribution towards continuing geophysical efforts aimed at improving our understanding of the enigmatic WSB (Damaske et al., 2003; Studinger et al., 2004), we present recent aeromagnetic data collected over its eastern margin.

\section{Regional setting}

The TAM are part of the Early Paleozoic Ross Orogen (e.g. Federico et al., 2006). Its structural architecture consists of a major fault belt, inherited from the Ross orogenic cycle and reactivated during the Cenozoic to form an intracontiental strike-slip deformation zone (Salvini et al., 1997). Cenozoic strike-slip faults cut across the thicker continental lithosphere of the TAM abutting along the thinned Ross Sea margin (Storti et al., 2001). These fault systems appear to segment the TAM into several discrete crustal blocks; tectonic blocks imaged so far from regional aeromagnetic analysis over the TAM include the Southern Cross Mountains Block, the Deep Freeze Range Block, and the Prince Albert Block (Ferraccioli and Bozzo 1999). The Prince Albert Mountains Block is marked by a broad, over $300 \mathrm{~km}$ long, magnetic high. The sources of the long-wavelength aeromagnetic high are largely buried magmatic arc rocks assigned to the Granite Harbour Intrusives (Ferraccioli and Bozzo, 1999). High-frequency anomalies over this block reveal large volumes of overlying Jurassic tholeiites, which are partially exposed (Fig. 1). A complex fault system flanks the Prince Albert Mountains Block (Prince Albert Fault System) and is composed of discrete fault zones, some of which are Cenozoic strike-slip faults, such as the Reeves Fault and the David Fault (Salvini and Storti, 1999). Further to the north, the Deep Freeze Range Block (Ferraccioli and Bozzo, 1999) is flanked to the west by the Priestley (Storti et al., 2001) and to the east by the Campbell Fault (Salvini et al., 1997), which also represent major Cenozoic strike-slip faults.

Ferraccioli and Bozzo (2003) suggested that strike-slip faulting identified from aeromagnetic imaging and structural evidence over the Prince Albert Mountains Block may continue along the eastern margin of the WSB, potentially linking to faults recognized over Oates Land, some $400 \mathrm{~km}$ further north (Flottmann and Kleinschmidt, 1993; Damaske et al., 2003; Ferraccioli et al., 2003; Kleinshmidt and Läufer, 2006). However, this hypothesis remained speculative due to the lack of any aeromagnetic coverage over this area. 


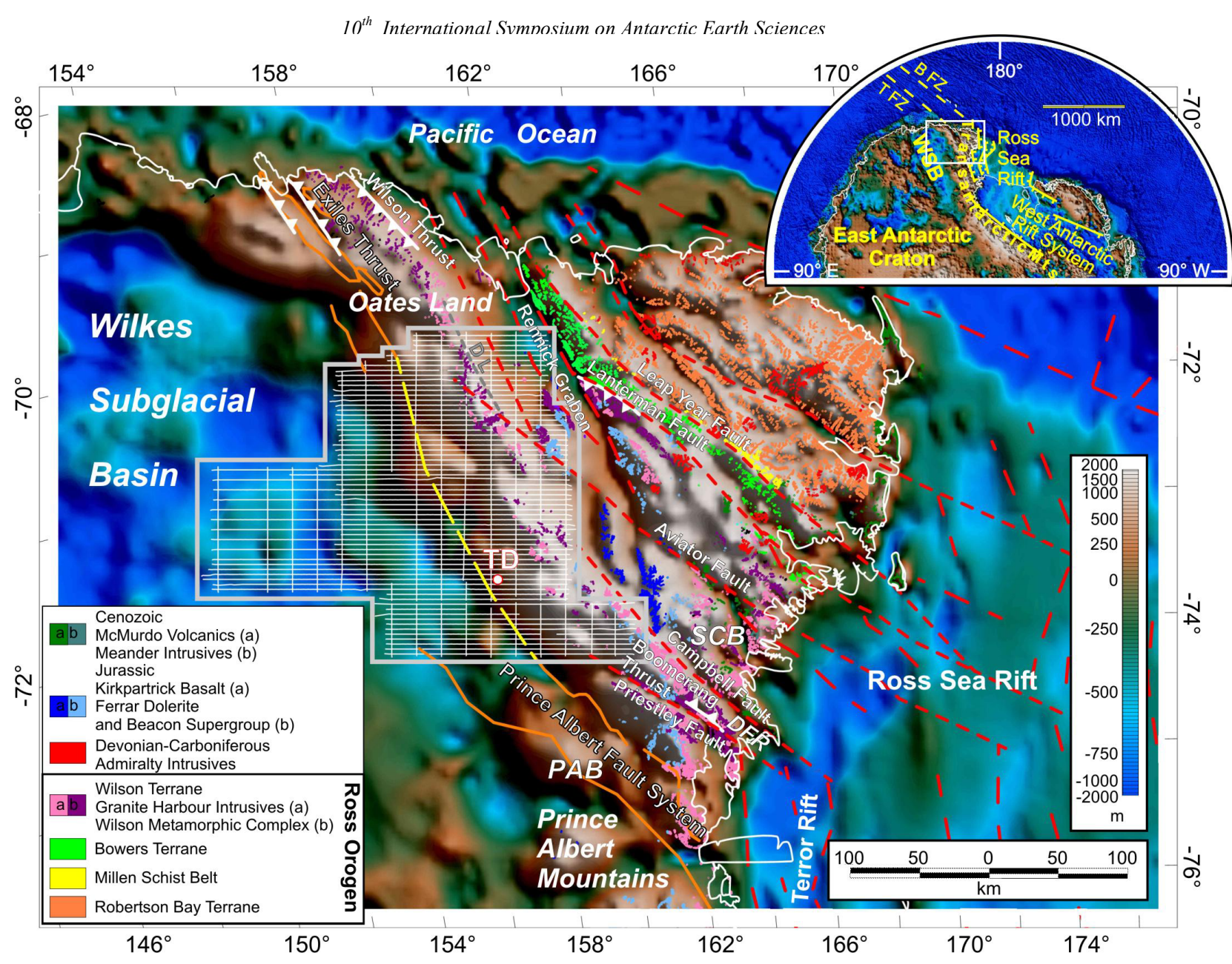

Figure 1. Tectonic sketch map for the Transantarctic Mountains/Wilkes Subglacial basin region, superimposed upon bedrock topography. Red lines delinate major Cenozoic strike-slip faults (Salvini et al., 1997). Grey box shows the location of the WIBEM aeromagnetic survey flown from Talos Dome (TD). Orange lines represent the major aeromagnetic lineaments and anomalies interpreted over the TAM prior to the survey. Yellow line shows the previously hypothesised connection between the Prince Albert Fault System and the Exiles Thrust region inferred to lie along the margin of the WSB (Ferraccioli and Bozzo, 2003). Inset shows the location of the study area with respect to the Ross Sea and the Transantarctic Mountains (West Antarctic Rift System). BFZ: Balleny Fracture Zone; TFZ: Tasman Fracture Zone; PAB: Prince Albert Mts. Crustal Block; DFR: Deep Freeze Crustal Block; SCM: Southern Cross Mts. Crustal Block.

\section{New aeromagnetic survey}

During the 2003-04 Antarctic field season the Italian Antarctic Programme performed a new aeromagnetic survey along part of the eastern margin of the WSB within the framework of the WIBEM (Wilkes Basin Eastern Margin) project, in order to provide a window on possible tectonic structures lying between the exposed TAM front and the basin itself (Armadillo et al., 2006). Approximately 18,000 line $\mathrm{km}$ of data were acquired over an area of $66,000 \mathrm{~km}^{2}$. Line spacing varied between 4,4 and $8,8 \mathrm{~km}$ with tie line interval of $22 \mathrm{~km}$. Nominal flight altitude was set to $3050 \mathrm{~m}$, with some deviations for higher topography. A ski-equipped Twin Otter was used to fly the survey, with the magnetic sensor installed in towed-bird configuration to avoid magnetic interference effects from the aircraft. The Twin Otter was equipped with an additional ferry tank, which extended the range of individual survey flights to over $1,500 \mathrm{~km}$ from the remote field camp of Talos Dome (Fig. 1).

Standard aeromagnetic processing included the base station correction, IGRF removal, levelling and microlevelling in frequency domain (Ferraccioli et al., 1998). Changes in the distance from sensor to magnetic source will lead to variable attenuation of the magnetic anomalies. This is particularly relevant since the survey spans from an area of high elevations over the TAM in the east (mean elevations over 2,000 m) to an area of subuded topography (up to $500 \mathrm{~m}$ below sea-level) to the west, over the WSB. To account for this, the aeromagnetic data were draped (Pilkington and Thurston, 2001) onto the BEDMAP subglacial topography grid (Lythe et al., 2000). The draping interval was set to 2800 $\mathrm{m}$, which represents the calculated mean distance from flight altitude to bedrock for the entire survey. The resulting total field aeromagnetic anomaly map is shown in Figure 2. 


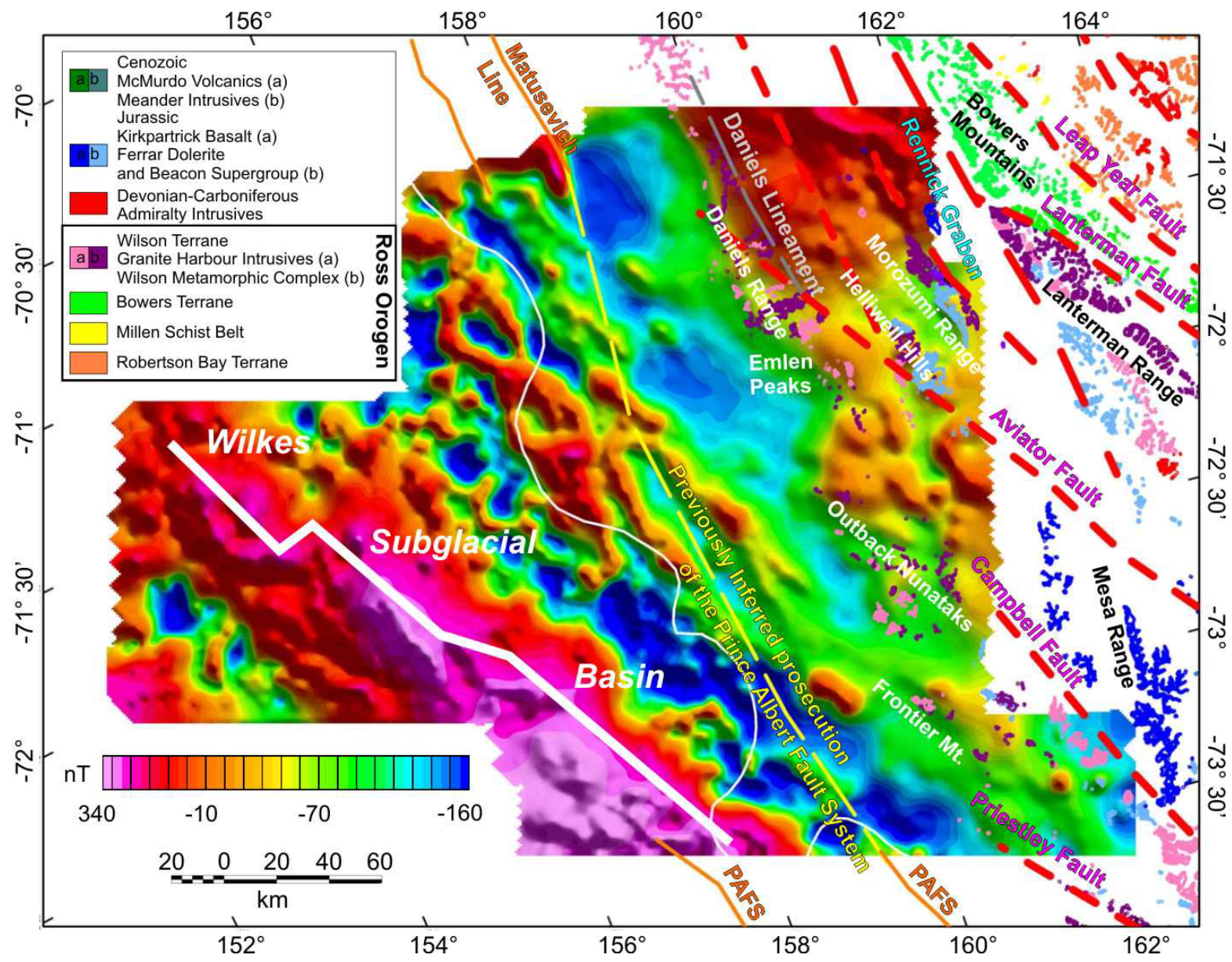

Figure 2. New aeromagnetic anomaly map for the transition zone between the Transantarctic Mountains and the Wilkes Sublgacial Basin. Note the belt of linear aeromagnetic anomalies apparently linking the Cenozoic trace of the Matusevich Fracture Zone with that of the Priestley Fault. These lineaments are interpreted to arise from hitherto unrecognized faults along the eastern margin of the WSB. Bold white line represents the major aeromagnetic lineament interpreted as representing the northern prosecution of the Prince Albert Fault System (PAFS). Thin white line is the $-250 \mathrm{~m}$ subglacial topography contour in the WSB.

\section{Interpretation}

The new anomaly map (Fig. 2) images a NW-SE oriented structural grain at the transition between TAM front and the ice-covered WSB, which matches the regional strike of the major Cenozoic faults of northern Victoria Land (Salvini et al., 1997). The western sector of the survey area is dominated by a long-wavelength (about $80 \mathrm{~km}$ ), high-amplitude positive anomaly. The sources of this regional magnetic high within the WSB are interpreted as buried Granite Harbour Intrusives of Rossage, as proposed for the Prince Albert Mountains further to the south (Ferraccioli and Bozzo, 1999). Highfrequency anomaly patterns, which are typically related to Ferrar tholeiites are visible though more difficult to discern here compared to the exposed TAM areas (due to greater distance to source). The presence of subglacial Ferrar rocks would be consistent with interpretations of previous aeromagnetic and land-based magnetic data further to the south across the WSB (Ferraccioli et al., 2001; Studinger et al., 2004). A broad lower amplitude positive anomaly is detected over the northeastern quadrant of the survey area, and overlies the Daniels Range and USARP Mountains. A prominent N-S oriented magnetic lineament flanks this high and we propose that it represents the prosecution of the Daniels Lineament mapped from previous aeromagnetic surveys (Ferraccioli et al., 2002). This lineament has been interpreted as a major fault separating a magnetite-rich Ross-age batholith from more weakly magnetic metasedimentary and arc rocks of the western Wilson Terrane (Ferraccioli et al., 2002).

Following Ferraccioli and Bozzo (2003), we tested the hypothesis that the Prince Albert Fault System may prosecute northward to join with the trace of the Exiles Thrust over Oates Land (Flottmann and Kleinschmidt, 1993). The new aeromagnetic map shows that although the Prince Albert Fault system does indeed continue in the WSB region, it lies considerably further to the west than previously postulated, and has a more pronounced NWSE strike. Recent structural data collected over Oates Land suggests that the Exiles Thrust is not simply a fossil Ross-age Fault, but might have been reactivated in post- 
Paleozoic (Cenozoic?) times to form the Matusevich Fracture Zone, which lies on strike with the Tasman Fracture Zone of the Southern Ocean (Kleinscmidt and Läufer, 2006).

Our new aeromagnetic map now suggests that a complex array of faults may connect the Exiles Thrust/Matusevich Fracture Zone over Oates Land to the Priestley Fault area at the Ross Sea Coast (Figs. 1 and 2). A connection between these basement fault zones along the eastern margin of the WSB would is also consistent with independent $\mathrm{K}-\mathrm{Ar}$ age data, suggesting that a Rossage pop-up structure is preserved from the Oates Land to the Ross Sea Coast (Adams, 2006). Ar-Ar dating of pseudotachylite-bearing fault cores documents that the Priestley Fault was indeed reactivated in the Cenozoic as a major strike-slip fault (Di Vincenzo et al., 2004). In addition, more recent interpretation of seismic data along the offshore extension of the Priestley Fault suggests Neogene-Recent activity of this fault system (Rossetti et al., 2006). Hence it appears likely that the inherited structural architecture, which we aeromagnetically imaged along the eastern margin of the WSB was also reactivated in the Cenozoic.

\section{Conclusions}

We have presented a new aeromagnetic anomaly map for the transition region located in-between the TAM and the WSB. The map suggests the existence of buried faults along the eastern margin of the WSB, which appear to connect faults previously mapped over Oates Land and at the Ross Sea Coast. This implies structural control on the eastern margin of the Wilkes Subglacial Basin, which contrasts with a purely flexural origin for the basin (Stern and ten Brink, 1989). Geological evidence over adjacent regions indicates that the faults along the eastern margin of the basin were likely to be active during the Ross Orogeny and reactivated during the Cenozoic as major strike-slip faults.

Acknowledgements Logistic and financial support has been provided by the Italian Antarctic Research Program (PNRA). The thoughtful and constructive reviews of three anonymous reviewers helped to improve this manuscript. The co-editor Jhon Gamble is gratefully acknowledged for providing constructive suggestions.

\section{References}

Adams C., J. (2006), Style of Uplift of Paleozoic Terranes in Northern Victoria Land, Antarctica: Evidence from K-Ar Age Patterns, in Futterer, Damaske, Kleinschmidt, Miller, and Tessensohn, (Eds): Antarctica - Contributions To Global Earth Sciences. Springer, 205214.

Armadillo E., E. Bozzo, G. Caneva, F. Ferraccioli and G. Tabellario, 2006. Recent Aeromagnetic and Deep Electromagnetic Exploration Projects in East Antartica. Terra Antartica Reports, 12, 167-176.

Damaske D., Ferraccioli F., \&and Bozzo E., 2003. Aeromagnetic Anomaly investigations along the Antarctic Coast between Yule Bay and Mertz Glacier. Terra Antartica, 10, 2/3, 85-96.

Di Vincenzo, G., Rocchi, S., Rossetti, F. and Storti, F. (2004), ${ }^{40} \mathrm{Ar}-$ ${ }^{40} \mathrm{Ar}$ dating of pseudotachylytes: the effect of clast-hosted extraneous argon in Cenozoic fault-generated friction melts from the West Antarctic Rift System. Earth and Planet. Sci. Lett., 223:349-364.

Drewry, D. J. (1976), Sedimentary basins of East Antarctic Craton from geophysical evidence, Tectonophysics, 36:301-314.

Federico, L., Capponi, G. and Crispini, L. (2006) Magnetic Petrology of the Ross Orogen in Oates Land (Antarctica), International Journal of Earth Sciences, 95(5):759-770.

Ferraccioli, F. and Bozzo, E. (1999), Inherited crustal features and tectonic blocks of the Transantarctic Mountains: An aeromagnetic perspective (Victoria Land, Antarctica). J. Geophys Res., 104:2529725320.

Ferraccioli, F. and Bozzo, E. (2003), Cenozoic strike-slip faulting from the eastern margin of the Wilkes Subglacial Basin to the western margin of the Ross Sea Rift: an aeromagnetic connection, in F. Storti, R. E. Holdsworth and F. Salvini, editors, Intraplate Strike-slip Deformation, volume 210 of J. Geol. Soc. Spec. Publ.

Ferraccioli, F., Bozzo, E. and Capponi, G. (2002), Aeromagnetic and gravity anomaly constraints for an early Paleozoic subduction system of Victoria Land, Antarctica, Geophys. Res. Lett., 29:44-1.

Ferraccioli, F., Coren, F., Bozzo, E., Zanolla, C., Gandolfi, S., Tabacco, I. and Frezzotti, M. (2001), Rifted(?) crust at the East Antarctic Craton margin: gravity and magnetic interpretation along a traverse across the Wilkes Subglacial Basin region, Earth and Planet. Sci. Lett., 192:407-421.

Ferraccioli, F., M. Gambetta, and E. Bozzo, 1998. Microlevelling procedures applied to regional aeromagnetic data: An example from the Transantarctic Mountains (Antarctica), Geophys. Prospect., 46, 177-196.

Fitzgerald, P.G., (2003), Tectonics and landscape evolution of the Antarctic plate since Gondwana breakup, with an emphasis on the West Antarctic rift system and the Transantarctic Mountains. In: Antarctica at the close of the millennium, Edited by J. A. Gamble et al., Royal Society of New Zealand Bulletin 35: 453-469

Flöttmann, T., and G. Kleinschmidt, (1993), The structure of Oates Land, Antarctica, Geol. Jahrb., Reihe E, 47, 419-436.

Kleinschmidt, G., and Läufer, A.L. (2006): The Matusevich Fracture Zone in Oates Land, East antartica. In: Antarctica: Contributions to global earth sciences, Edited by D:K: Fütterer et al., Heidelberg (Springer), 175-180.

Lythe, M. B., D. G. Vaughan, and C. BEDMAP (2001), BEDMAP: A new ice thickness and subglacial topographic model of Antarctica, $J$. Geophys. Res., 106(B6), 11,335-11,352

Pilkington, M. and Thurston, B. J. (2001), Draping corrections for aeromagnetic data: line- versus grid-based approaches. Exploration Geophysics, 32:95-101.

Rossetti, F., F. Storti, M. Busetti, F. Lisker, G. Di Vincenzo, A.L. Laufer, S. Rocchi, F. Salvini, 2006. Eocene initiation of Ross Sea dextral faulting and implications for East Antarctic neotectonics. Journal of the Geological Society 163, 1, 119-126 .

Salvini, F. and Storti, F. (1999), Cenozoic tectonic lineaments of the Terra Nova Bay region, Ross Embayment, Antarctica. Glob. Planet. Change, 23:129-144.

Salvini, F., Brancolini, G., Busetti, M., Storti, F., Mazzarini, F. and Coren, F. (1997), Cenozoic geodynamics of the Ross Sea region, Antarctica: crustal extension, intraplate strike-slip faulting, and tectonic inheritance, J. Geophys. Res., 102:24669-24696.

Steed, R. H. N. (1983), Structural interpretation of Wilkes Land, Antarctica, in R. L. Oliver, P. James and J. B. Jago, editors, Antarctic Earth Science-Proc. Fourth Int. Symp. Antarct. Earth Sci, pages 567572 Cambridge University Press, New York.

Stern, T. A. and ten Brink, U. S. (1989), Flexural uplift of the Transantarctic Mountains, J. Geophys. Res., 94:10315-10330.

Stern, T.A. and Baxter, A. (2003), Glacial erosion and rock uplift with the Transantarctic Mountains. In: Antarctica at the close of the millennium , Edited by J. A. Gamble et al., Royal Society of New Zealand Bulletin 35: 471-478., 2004

Storti, F., Rossetti, F. and Salvini, F. (2001), Structural architecture and displacement accommodation mechanisms at the termination of the Priestley Fault, northern Victoria Land, Antarctica, Tectonophysics, 341(1-4):141-161.

Studinger, M., Bell, R.E., Buck, W.R., Karner,G.D., and Blankenship, D.D.(2004), Sub-ice geology inland of the Transantarctic Mountains in light of new aerogeophysical data, Earth Planet. Sci. Lett., 220, 391-408 